\title{
Technical efficiency of goat farming in Turkey: a case study of Isparta province
}

\author{
Mevlüt Gül1', Vecdi Demircan1, Hasan Yilmaz', Hilal Yilmaz²
}

\author{
${ }^{1}$ Süleyman Demirel University, Faculty of Agriculture, Department of Agricultural Economics, Isparta, Turkey. \\ ${ }^{2}$ Eastern Mediterranean Agricultural Research Institute, Adana, Turkey.
}

\begin{abstract}
This study estimates the technical efficiency of goat rearing in the province of Isparta in Turkey using Data Envelopment Analysis (DEA). The data used were collected from 92 goat farmers using the stratified sampling method by means of a questionnaire. The technical efficiency of the goat farming varied widely between 0.13 and 1.00 . The mean efficiency of 92 goat farms was calculated to be 0.44 and 0.66 for constant and variable returns to scale assumptions, respectively. The greatest slacks were in feedstuff concentrates and labour used. The most significant factors affecting efficiency of goat production were farmer experience, cooperative membership, milk yield per goat, and family and hired labour. Technical efficiency should be improved by providing farmers with well-organised education, an extension program, and research and development programs on goat rearing.
\end{abstract}

Key Words: characteristic, data envelopment analysis, farm, socio-economics

\section{Introduction}

Livestock production is an important sector in the Turkish national development in producing food, increasing external trade, ensuring a balanced development between areas and sectors, and reducing unemployment in rural areas, in addition to creating new employment opportunities in the industrial and service sectors.

Goat production occupies an important position in the livestock sector in Turkey. Approximately $2.7 \%$ of meat production and $2.5 \%$ of milk production in Turkey derive from goats (TUIK, 2014). Goat production provides significant employment in pasturing. The climate and vegetation of Anatolia make it suitable for livestock rearing and especially for goats. The arid climatic conditions and the extensive plateau and pasture area in Turkey are especially suitable for livestock farming. Turkey is a rich country in terms of goat production. This wealth is fostered by the natural climatic conditions and the traditional agriculture structure. The most important provinces for goat production in Turkey are Mersin, Antalya, Adana, Siirt, Mardin, Bitlis, Diyarbakır, Şırnak, Kahramanmaraş, Muğla, Van, Isparta, and Muğla. Isparta is ranked 12th in

Received August 15, 2015 and accepted March 8, 2016.

Corresponding author: mevlutgul@sdu.edu.tr

http://dx.doi.org/10.1590/S1806-92902016000600007

Copyright $\odot 2016$ Sociedade Brasileira de Zootecnia. This is an Open Access article distributed under the terms of the Creative Commons Attribution License (http://creativecommons.org/licenses/by/4.0/), which permits unrestricted use, distribution, and reproduction in any medium, provided the original work is properly cited. terms of goat production in Turkey. The number of goats in Isparta is very high. Small ruminant production depends largely on the available pasture in the province and in Turkey.

Isparta had a total of approximately 237,500 goats in 2013. Isparta has $2.3 \%$ of the total number of goats in Turkey. However, productivity is low compared with other provinces. The most important goat breed found in Isparta is the hair goat (TUIK, 2014).

Although Turkey is a suitable country for stockbreeding, policies are inadequate to improve goat production. Goat numbers are large but production is insufficient. In recent years, structural and economic problems have increased. In this respect, it is important to improve animal production and analyse management structure in order to solve animal production problems. Sheep and goat rearing is generally conducted extensively in Turkey: the animal products obtained constitute the main sources of nutrition for lowincome farms, contribute to income, and create employment opportunities for labour (Dellal et al., 2002).

The number of goats in Turkey is approximately 10.4 million, $98.3 \%$ of which are hair goats and $1.7 \%$ are Angora goats. Annual production of goat milk in Turkey is 463 thousand tons. Isparta province, where the present study was conducted, plays an important role in goat rearing within Turkey, as 9,984 tons of goat milk are produced in the study region (TUIK, 2014).

A considerable amount of research has been conducted on goat farming production structure and its cost and profitability. Panayiotou (1989) determined the economic 
structure of sheep and goat farms in Cyprus. Papanagiotou (1991) calculated the profitability of goat farming in Greece. Gebremedhin and Gebrelul (1992) examined small-scale goat farms by selecting three production systems and compared the net present value, financial feasibility analysis, and payback period scores. Brandano et al. (1992) studied the quality and quantity of goat farm production activities in Italy. Deoghare and Bhattachryya (1993) carried out economic analysis of goat production in selected areas of India. Darwich (1998) examined the economics of small animal production in Jabel Abdel Aziz of Syria. Dellal (2000) examined the economic structures and annual performance of hair goat farms in Antalya province and derived optimum farm plans under existing production conditions. She found that the percentage of gross production value (GPV) from hair goat breeding was $65.20 \%$ of total GPV. Also, she found that large farms were more successful than small farms. Fousekis et al. (2001) noted that subsidies can be negatively associated with levels of efficiency, and there has recently been a strong debate regarding the discontinuation of such regimes within the European Union (EU). De Rancourt et al. (2006) compared the condition of main small ruminant systems in Southern Europe and their possible future evolution, and the authors concluded that in the different countries and production sectors, extensive systems were dominant because of the less favoured areas frequently used by small ruminants. Araç (2007) determined the structural characteristics of goat farms in Diyarbakır province. Paksoy (2007) analysed the economic structure of goat farming in Kahramanmaraş province and reported that large farms were more successful than small ones. Ruiza et al. (2009) analysed and proposed improvements for the dairy goat grazing systems in Spain, France, and Italy. They identified the main weaknesses relating to feeding management, particularly grazing and goat productivity. Özdemir (2009) investigated the structural and breeding characteristics and health protection practices of Angora goat farms. Toussaint et al. (2009) presented the work undertaken since 1994 by a working group of experts from sub-network FAO-CIHEAM on systems of sheep and goat production, and on the methodology of the evaluation of such systems. Acar (2010) determined the technical and structural characteristics of the Member Enterprises of the Isparta Sheep and Goat Breeding Association. He found that farms had many technical and structural problems such as breeding, nutrition, health management, housing and grazing. Çıtak (2011) determined that large-scale goat farms were more successful than small farms. Gaspar et al. (2011) studied dairy goat systems in Cáceres, Spain. The authors collected specific information on management with data on family characteristics, labour, livestock numbers, land use, installations, continuity, recent changes in farming, and the opinions of farmers. They found that the best management practices and productivity results were on the farms furthest removed from the traditional systems.

No study has been done on the production efficiency of goat rearing in Turkey, however, and the present study, which examines the production efficiency of goat rearing in the province of Isparta in Turkey, is very relevant to the competitive pressures confronting the Turkish goat sector and the importance of the goat sector in Turkey. The purpose of the study was to investigate the technical efficiency of goat rearing in Turkey based on primary data obtained from farmers in Isparta province. For this reason, a nonparametric method (data envelopment analysis) was used.

\section{Material and Methods}

The main material of this study is primary data collected from goat farmers in the province of Isparta, in Turkey, through the use of a questionnaire. Isparta has $2.3 \%$ of the total number of goats in Turkey. The data used were for the 2007 production season, and the survey was conducted in 26 villages located within the boundaries of the central, Atabey, Keciborlu, Egirdir, and Sutculer districts of Isparta province. The Neyman stratified sampling procedure was employed in selecting goat farms in order to decrease variance, form homogeneous stratification, and represent different production units. Sampling size was found to be 92 farms (Table 1).

Battese (1992) pointed out that both parametric and non-parametric methods are used to measure efficiency. Deterministic frontier production functions, stochastic frontier methods, and panel data models are parametric methods. One of the non-parametric methods which are widely used in efficiency measurement studies is Data Envelopment Analysis (DEA). Hansen et al. (2002) identified the advantages of DEA as a method that does not need a distributional form to be specified for the production function and the inefficiency term. In this method, each production unit is given an efficiency score based on its

Table 1 - Farm groups and number of interviewed farms

\begin{tabular}{lcc}
\hline $\begin{array}{l}\text { Herd size } \\
\text { (number of goats) }\end{array}$ & $\begin{array}{c}\text { Farms sampled } \\
\text { (number) }\end{array}$ & $\begin{array}{c}\text { Distribution of sampled } \\
\text { farmers }(\%)\end{array}$ \\
\hline $1-100$ & 34 & 36.96 \\
$101-300$ & 26 & 28.26 \\
$301-+$ & 32 & 34.78 \\
Total & 92 & 100.00 \\
\hline
\end{tabular}


distance from a production frontier constructed by means of a linear programming model. No explicit functional form is assumed for the underlying production technology in DEA (Hansen et al., 2002).

Coelli et al. (1998) expressed efficiency in two principal ways. These are input-oriented and output-oriented measures. An input-oriented Banker-Charnes-Cooper (BCC) model is given below for $\mathrm{n}$ decision-making units (DMU), each producing $\mathrm{M}$ outputs by using $\mathrm{K}$ different inputs (Coelli et al., 1998; Coelli et al., 2005):

$$
\begin{aligned}
& \text { Min } \theta, \lambda \quad \theta \\
& \text { subject to } \\
& -\mathrm{y}_{\mathrm{i}}+\mathrm{Y} \lambda \geq 0 \\
& \theta \mathrm{x}_{\mathrm{i}}-\mathrm{X} \lambda \geq 0 \\
& \mathrm{~N} 1^{\prime} \lambda=1 \\
& \lambda \geq 0
\end{aligned}
$$

in which $\theta$ is a scalar; $\mathrm{N} 1^{\prime}$ is convexity constraint; $\lambda$ is $\mathrm{N} \times 1$ vector of constants; $\mathrm{Y}$ represents output matrix; and $\mathrm{X}$ represents input matrix. The value of $\theta$ will be the efficiency score for firm $\mathrm{i}$. This linear programming problem must be solved $\mathrm{N}$ times, once for each firm in the sample. A $\theta$ value of one indicates that the firm is technically efficient according to the definition of Farrell (1957) (Coelli et al., 1998). Coelli (1996; 1997) developed this multi-stage methodology and a computer program that implements a robust multi-stage model among other options. In this study, the DEA model was employed because farmers have more control over inputs than outputs, and so the input-oriented DEA model was used.

Data Envelopment Analysis models have been applied to many theoretical and empirical works in economics and operations research studies and are extensively used in practice to compare firms that are different. Data Envelopment Analysis has been used in a number of analyses and also as basis for advice to farmers, e.g., Lund and Ørum (1997) and Gerber and Franks (2001), and some examples of DEA for livestock production analysis can be traced in the following sources: Cloutier and Rowley (1993), Fraser and Cordina (1999), Reinhard et al. (2000), Fousekis et al. (2001), Galanopoulos et al. (2006), Hansson (2007), Dağistan et al. (2009), Gaspar et al. (2009), and Meensel et al. (2010).

The model is specified as having one output and four inputs. The gross value of goat production (converted to USD per unit animal) represents the output. The goat population represents animal units (AU) by means of coefficients. In this conversion to animal units, female goats, male goats, yearlings, and kids had coefficients of $0.1,0.12,0.08$, and
0.05, respectively (Erkus et al., 1995). Four inputs (labour, feedstuff concentrates, roughage feedstuff, and veterinary costs) were used in the analyses. Labour input consists of both hired and family labour used per animal unit.

The gross product value is the calculated market values of products produced as a result of goat farming (meat, milk, cheese, butter, hair, manure, etc.) plus appreciation in yearly assets. Relative return is calculated by dividing the gross product value by total production costs (Rehber and Tipi, 2005).

After calculating DEA technical efficiency scores, a two-tailed Tobit model was employed to identify sources of inefficiencies, because efficiency scores range between 0 and 1 and most of the literature (Gül, 2005; Alemdar and Ören, 2006; Gül, 2006; Alemdar and Işik, 2008; Dağistan et al., 2009; Koc et al., 2011) used the Tobit model to find inefficiencies.

In the analysis of the descriptive statistics on physical input and output parameters (Table 2), some of the inputs showed large variations. The greatest variations were observed in labour $\left(\mathrm{h} \mathrm{AU}^{-1}\right)$, concentrates, $\left(\mathrm{kg} \mathrm{AU}{ }^{-1}\right)$, and roughage feedstuffs $\left(\mathrm{kg} \mathrm{AU}^{-1}\right)$, when coefficients of variation are taken into consideration. It is also clear from Table 2 that some farmers are not using all of these feedstuffs. In the research area, $21.74 \%$ of goat producers did not use concentrates and roughage as feedstuffs. This means that they did not provide supplementary feeding and only grazed their animals on pasture.

Great variations in input use levels may be an indicator of problems of mismanagement or lack of technical know-how.

Efficiency scores were regressed with several socioeconomic features to determine the factors of inefficiency.

\section{Results}

Goat farming activities in this area are carried out by families. The pasturing period of animals is an average of

Table 2 - Summary statistics for variables used in the efficiency analysis

\begin{tabular}{lcccc}
\hline Input/output variable & Minimum & Maximum & Mean & SD \\
\hline $\begin{array}{l}\text { Output } \\
\quad \text { Gross product value }\end{array}$ & 77.64 & 1282.38 & 514.25 & 220.69 \\
$\quad\left(U S D \mathrm{AU}^{-1}\right)$ & & & & \\
Inputs & & & & \\
Labour (h AU & & & & \\
Concentrates $\left(\mathrm{kg} \mathrm{AU}^{-1}\right)$ & 0.00 & 1546.76 & 276.64 & 286.05 \\
Roughage $\left(\mathrm{kg} \mathrm{AU}^{-1}\right)$ & 0.00 & 1773.65 & 155.77 & 286.90 \\
$\quad$ Veterinary cost $\left(\mathrm{USD} \mathrm{AU}^{-1}\right)$ & 0.00 & 133.65 & 32.88 & 23.14 \\
\hline
\end{tabular}

SD - standard deviation; USD - American Dollars; AU - animal unit. 
348.21 days per year. Goat production in the study area is conducted only for milk and meat. Sixty-six per cent of the growers reported visits from extension staff. The use of family labour is general in the study area, but $18.48 \%$ of farms used both family and hired labour. However, the enterprises averaged $31.52 \%$ cooperative membership and $25.00 \%$ agricultural credit use. The average age of farmers was calculated to be 50.51 years, their mean educational level was 5.18 years, and they had 25.33 years of farming experience. The average milk yield, lactation period, kid yield, and average size of farm were determined to be 0.41 $\mathrm{kg}$ days $^{-1}, 5.05$ months, $108.89 \%$, and 1.96 ha, respectively. Some of the goat farms in the research area $(71.7 \%)$ also produced other crops. These crops were mostly wheat, barley, rose oil, and feed crops. Their goats were grazed on public pasture and forest area.

The mean non-agricultural income rate was $7.07 \%$. The average number of people per farm was calculated to be about 5 , and the average number of goats per farm was approximately 251 , while goat production value amounted to $56.76 \%$ of total income (Table 3 ).

Data Envelopment Analysis scores were calculated using DEAP software version 2.1, developed by Coelli (1996).

Out of the 92 goat farms in the sample, six farms $(6.52 \%$ of all goat farms) under constant return to scale (CRS) and 41 farms ( $44.57 \%$ of all goat farms) under variable return to scale (VRS) were found to be fully efficient. Forty-six farms (50.00\% of all goat farms) under CRS and 29 farms (31.52\% of all goat farms) under VRS showed a performance of below 0.40 (Table 4). Predicted technical efficiencies differed among sample farms, ranging between 0.06 and

Table 3 - Socioeconomic indicators in goat rearing

\begin{tabular}{lc}
\hline Indicator & Average \\
\hline Farmer age (years) & 50.51 \\
Farmer education level (years) & 5.18 \\
Population of enterprises (no. of people) & 4.75 \\
Farmer experience with goat rearing (years) & 25.33 \\
Total farm land (ha) & 1.96 \\
Distance to pasture area from farm (km) & 3.74 \\
Milk yield (kg day $\left.{ }^{-1}\right)$ & 0.41 \\
Total number of goats per farm (heads farm $\left.{ }^{-1}\right)$ & 250.75 \\
Total animal units (AU farm $\left.{ }^{-1}\right)$ & 20.21 \\
Fertility (\%) & 108.89 \\
Grazing duration (days) & 348.21 \\
Lactation period (months) & 5.05 \\
Visits of extension staff to farmers (\%) & 66.30 \\
Feeding only on pasture $(\%)$ & 21.74 \\
Also used non-family labour (\%) & 18.48 \\
Membership of cooperatives (\%) & 31.52 \\
Used credit (\%) & 25.00 \\
Goat production value in total income (\%) & 56.76 \\
Non-agricultural income in total income $(\%)$ & 7.07 \\
\hline AU - animal unit. &
\end{tabular}

AU - animal unit.
1.00 , with a mean technical efficiency of 0.66 (Table 4). These results indicate that there are some opportunities for improving resource use efficiency. Sample farms may reduce their input by $34 \%$ on average while remaining at the same production level.

In a linear programming model, slack values are derived by converting inequality constraints to equality constraints and adding slack variables (Walden and Kirkley, 2000). The "slack" identifies excess input or missing output that exists even after the proportional change in the input or the outputs (Shim, 2003). Slack variables are also analysed to determine excess input use. It can be said that a farm can reduce its expenditure on an input by the amount of slack without reducing its output. The greatest input excess was in feedstuff concentrates used (Table 5). The average amounts of feedstuff concentrates, labour used, roughage feedstuff, veterinary costs, and GPV used by the 41 efficient farms under VRS assumption were $209.43 \mathrm{~kg} \mathrm{AU}^{-1}, 811.03 \mathrm{~h} \mathrm{AU}^{-1}$, $87.49 \mathrm{~kg} \mathrm{AU}^{-1}$, USD $31.56 \mathrm{AU}^{-1}$, and USD $573.41 \mathrm{AU}^{-1}$ respectively.

For the inefficient farms, the causes of inefficiency may be either inappropriate scale or misallocation of resources. Inappropriate scale suggests that the farm is not taking advantage of economies of scale, while misallocation of resources refers to inefficient input combinations. Therefore, inefficiencies could be mainly due to improper input use.

Table 4 - Frequency distributions of technical efficiency scores obtained with Data Envelopment Analysis model

\begin{tabular}{lccc}
\hline \multirow{2}{*}{ Efficiency score } & \multicolumn{3}{c}{ Data Envelopment Analysis } \\
\cline { 2 - 4 } & CRS & VRS & SE \\
\hline 1.00 & 6 & 41 & 6 \\
$0.91-0.99$ & 1 & 1 & 10 \\
$0.81-0.90$ & 4 & 1 & 14 \\
$0.71-0.80$ & 6 & 3 & 15 \\
$0.61-0.70$ & 8 & 3 & 18 \\
$0.51-0.60$ & 6 & 5 & 9 \\
$0.41-0.50$ & 15 & 9 & 12 \\
$<0.41$ & 46 & 29 & 8 \\
Minimum & 0.04 & 0.06 & 0.13 \\
Maximum & 1.00 & 1.00 & 1.00 \\
Mean & 0.44 & 0.66 & 0.69 \\
\hline
\end{tabular}

CRS - constant return to scale; VRS - variable return to scale; SE - scale efficiency.

Table 5 - Input slacks and number of farms using excess inputs

\begin{tabular}{|c|c|c|c|c|}
\hline Input & $\begin{array}{l}\text { Number of } \\
\text { farms }\end{array}$ & $\begin{array}{l}\text { Mean } \\
\text { slack }\end{array}$ & $\begin{array}{c}\text { Mean } \\
\text { input use }\end{array}$ & $\begin{array}{c}\text { Excess input } \\
\text { use }(\%)\end{array}$ \\
\hline Labour (h AU $\left.{ }^{-1}\right)$ & 44 & 254.81 & 1080.02 & 23.59 \\
\hline Concentrates $\left(\mathrm{kg} \mathrm{AU}^{-1}\right)$ & 60 & 79.81 & 276.64 & 28.85 \\
\hline Roughage (kg AU $\left.{ }^{-1}\right)$ & 26 & 24.27 & 155.77 & 15.58 \\
\hline Veterinary cost $\left(\mathrm{USD}^{\mathrm{A}} \mathrm{AU}^{-1}\right)$ & 1) 30 & 6.99 & 32.88 & 21.26 \\
\hline
\end{tabular}


Scale efficiency (SE) of farms is calculated as the ratio between the technical efficiency CRS score and technical efficiency VRS score with DEAP. These scores can be from 0 to 1 . If the scale efficiency is less than 1 , the DMU will be operating either at decreasing returns to scale (DRS) if a proportional increase of all input levels produces a less-than-proportional increase in output levels or increasing return to scale (IRS) at the converse case (Boussofiane et al., 1992). The mean scale efficiency of the sample goat farms was calculated to be 0.69 . Out of the 92 goat farming enterprises, six showed constant returns to scale and 73 showed increasing returns to scale, whilst 13 farms were operating under decreasing returns to scale conditions.

Increased herd size also increased optimal ratio, but this was not statistically significant (Table 6). A herd size of between 101 and 300 had the highest percentage of decreasing return to scale, $15.38 \%$. The highest increasing return to scale, $84.38 \%$, was found in a herd size of 301 and above. The visits of extension staff were more frequent in the decreasing return to scale farms with $84.62 \%$. The highest modal of family labour used was found in constant return to scale farms and amounted to $100.00 \%$. However, $46.15 \%$ cooperative membership and 38.46\% agricultural credit use were the highest modal and were found in decreasing return to scale farms. The constant return to scale farm had the highest modal average age of the farmer, which was calculated to be 57.00 years. The decreasing return to scale farm had the highest modal of the following indicators: farming experience, milk yield, lactation period, kid yield, and farm land size of $29.15 \mathrm{yr}$, $0.83 \mathrm{~kg}, 5.46$ months, $114.00 \%$, and 2.49 ha, respectively. Additionally, the constant return to scale farm also had the highest share of duration on pasturing, with 365.00 days, and a non-agricultural income rate of $15.00 \%$. The highest score of population (about five people), number of goats (approximately 92 goats), total number of goats (approximately 259 goats), and goat production value $(58.89 \%)$ were found on increasing return to scale farms (Table 6).

To obtain information on factors affecting efficiency, efficiency scores were regressed upon various social, economic, and technical features. Technical efficiency scores of DEA were regressed on farm-specific characteristics to identify sources of inefficiencies. Since efficiency scores range between 0 and 1, a two-tailed Tobit model was employed in place of ordinary least squares (OLS) regression (Ray, 2004).

Farming experience (10\%), cooperative membership $(5 \%)$, milk yield (1\%), and labour (1\%) had a significant effect on efficiency scores (Table 7).

The signs of the parameters were as expected. Farming experience, cooperative membership, and milk yield parameters were positive. This indicates that more farming experience, cooperative membership, and greater milk yield increase efficiency. Labour, with a negative sign at the $1 \%$ statistical level, affects efficiency adversely.

Table 6 - Socioeconomic indicators by return to scale

\begin{tabular}{|c|c|c|c|}
\hline Indicator & Increasing return to scale & Constant return to scale & Decreasing return to scale \\
\hline Herd size (1-100 goats) (\%) & 76.47 & 8.82 & 14.71 \\
\hline Herd size (101-300 goats) (\%) & 76.92 & 7.69 & 15.38 \\
\hline Herd size (301 or more goats) (\%) & 84.38 & 3.13 & 12.50 \\
\hline Visit of extension staff to farmers (\%) & 63.01 & 66.67 & 84.62 \\
\hline Used only family labour (\%) & 82.19 & 100.00 & 69.23 \\
\hline Cooperative membership (\%) & 30.14 & 16.67 & 46.15 \\
\hline Agricultural credit used (\%) & 21.92 & 33.33 & 38.46 \\
\hline Farmer age (years) & 50.12 & 57.00 & 49.69 \\
\hline Farmer experience (years) & 24.74 & 24.17 & 29.15 \\
\hline Milk yield $\left(\mathrm{kg} \mathrm{day}^{-1}\right)$ & 0.32 & 0.58 & 0.83 \\
\hline Population (no. of people) & 4.88 & 3.50 & 4.62 \\
\hline Distance to pasture area from farm $(\mathrm{km})$ & 3.96 & 2.50 & 3.08 \\
\hline Doe (number of does) & 91.34 & 85.67 & 90.46 \\
\hline Lactation period (months) & 4.99 & 5.00 & 5.46 \\
\hline Total number of goats & 258.64 & 181.83 & 238.23 \\
\hline Fertility (\%) & 107.84 & 110.67 & 114.00 \\
\hline Grazing duration (days) & 346.85 & 365.00 & 348.08 \\
\hline Relative return & 1.07 & 1.91 & 1.60 \\
\hline Feeding cost share in total production cost $(\%)$ & 21.73 & 15.82 & 26.76 \\
\hline Goat production value in total income $(\%)$ & 58.89 & 37.50 & 53.69 \\
\hline Non-agricultural income in total income $(\%)$ & 6.99 & 15.00 & 3.85 \\
\hline Farm land (ha) & 1.89 & 1.42 & 2.49 \\
\hline
\end{tabular}




\section{Discussion}

In this study, the feeding cost share was calculated as $21.09 \%$ of total production cost. Gonçalves et al. (2008) found that herd feeding was the most important item in productive systems, varying between 60 and $70 \%$ of the total cost in the southeast of Brazil. In the research area, farmer feeding systems generally depend on grazing, and farmers only use supplemental feed for two or three months especially after births or in hard winter conditions. For this reason, feeding cost was low in the research area. Also, $21.74 \%$ of farms used only grazing and did not use supplemental feed.

Vieira et al. (2009) calculated milk yield as 441 and $606 \mathrm{~L} /$ goat and fertility was $86.95 \%$ and $85.71 \%$ in two types of goat farms in Brazil. In this study, milk yield was $62.12 \mathrm{~L} /$ goat and fertility was calculated as $108.89 \%$. In the study region, the farms had mostly hair goats, and the milk yield of these animals is low. This is because hair goats are low-yielding breeds with higher fertility rates, while the yield of Saanen goats is higher but their fertility is lower than those of hair goats.

Santos Junior et al. (2008) found that the income share of dairy goat husbandry was approximately $42 \%$ of total income in Brazil. In this study, this indicator share was slightly higher and calculated as $56.76 \%$. This indicated that goat husbandry was very significant to family income in the farms surveyed.

According to our results, $29.35 \%$ of the farms were not profitable as their relative returns were smaller than 1, and it was found that relative return tended to increase in parallel with the efficiency of the farm $(\mathrm{P}<0.01)$. The relative profit of the farm at constant return to scale level was calculated as 1.91. The lowest value (1.07) was obtained at increasing return to scale level of farms (Table 6).

Table 7 - Results of tobit regression analysis

\begin{tabular}{lcccc}
\hline Variable & Coefficient & SE & z-score & Significance \\
\hline Constant & 0.180806 & 0.156550 & 1.154944 & 0.2481 \\
Goat units (AU) & 0.000680 & 0.001165 & 0.584002 & 0.5592 \\
Farmer education level & 0.016903 & 0.010799 & 1.565210 & 0.1175 \\
Farmer age & 0.002792 & 0.001941 & 1.438134 & 0.1504 \\
Farmer experience & 0.002951 & 0.001637 & 1.802817 & 0.0714 \\
Cooperative & 0.089462 & 0.042102 & 2.124883 & 0.0336 \\
memberships & & & & \\
Milk yield (per goat) & 0.188238 & 0.069366 & 2.713698 & 0.0067 \\
Labour (family & -0.185193 & 0.052776 & -3.509023 & 0.0004 \\
and hired) & & & & \\
R-square & & & & 0.210008 \\
Adjusted R-square & & & & 0.133864 \\
\hline
\end{tabular}

$\mathrm{AU}$ - animal unit; SE - standard error.
Galanopoulos et al. (2011) applied DEA to a sample of transhumance farms in Greece to assess the technical efficiency of sheep and goat transhumance flocks, and determined the factors that affect their performance. They found that the overall technical efficiency of transhumance farms was quite low (this score amounted to 0.476 without subsidy and was calculated as 0.513 with subsidy) and that it was affected by herd size. They stated that EU subsidies had a significant impact on the technical efficiency of only the low-efficiency, small-sized farms.

Goat farming as the exclusive activity is a reality to $28.3 \%$ of farmers, while $71.7 \%$ of farms also had income from crops and other animals. In the research area, goat breeding is usually carried out in forest villages, which restricts sources of income to farmers. Goat farming is the most important income for growers surveyed in this study. Farmers practice traditional farming. The geographic conditions of the region are more suitable for keeping hair goats. Farmers stated that the costs of hair goat farming were lower than keeping Saanen goats.

A total of $40.22 \%$ of farmers sold their products to preferred customers, a form of direct marketing. Doing this reduced their marketing costs. Of the total, $23.91 \%$ sold their products in the local market, which increased production costs because of transportation, other fees and taxes, and $35.87 \%$ of farms sold their products to wholesalers.

This study found that age was positively related to production efficiency, but was not statistically significant (Table 7). Findings from previous empirical studies were mixed. For example, Abdulai and Huffman (1998), Alemdar and Işik (2008), and Gul et al. (2009) found that older farmers were less efficient than younger farmers, while Alemdar and Ören (2006) and Koc et al. (2011) found that older farmers were more efficient than younger farmers.

Education was positively associated with efficiency, but it was not statistically significant (Table 7). Similar results were reported for farmers in Turkey (Alemdar and Işik, 2008; Gul et al., 2009; Demircan et al., 2010; Parlakay et al., 2015), Pakistan (Battese et al., 1996), Cameroon (Binam et al., 2004), and Nigeria (Idiong, 2007). However, some authors stated that there was a negative relationship between education level and efficiency (Kaliba and Engle, 2004; Alemdar and Ören, 2006; Cinemre et al., 2006; Koc et al., 2011; Parlakay et al., 2015).

Cooperative membership was positively related to efficiency and statistically significant at the 5\% level of statistical confidence (Table 7). This implies that the efficiency of the goat farmer will increase with an increase in their membership of associations. Similar results were reported for farmers in Nigeria (Idiong, 2007; 
Omonona et al., 2010) and Turkey (Cinemre et al., 2006). In contrast to our finding, Binam et al. (2004) and Chirwa (2003) found that there was a negative relationship between club membership of a household member and efficiency in Cameroon and Malawi and statistically significant at the $1 \%$ level.

Farmer experience was statistically significant and had the expected sign (Table 7). Farmers who have more experience increase efficiency scores. Our result showed that there was a positive relationship between experience and efficiency, confirming the results of Mathijs and Vranken (2000), Binam et al. (2004), Gül (2006), Idiong (2007), Alemdar and Işik (2008), Gul et al. (2009), Omonona et al. (2010), and Parlakay et al. (2015). However, some authors found that there was a negative relationship between experience and efficiency (Kaliba and Engle, 2004; Alemdar and Ören, 2006; Cinemre et al., 2006).

Milk yield per goat had a positive relationship with farm efficiency. This relationship was significant at the $5 \%$ level of statistical confidence (Table 7).

\section{Conclusions}

Goat rearing is mainly based on pasturing. Goat farming in Isparta is strongly oriented towards meat and milk production and making milk products. Goat rearing in the study area is mainly done according to traditional methods. This can be improved through appropriate technical interventions such as using extension workers to educate farmers on new and improved technology, which will lead to sustainable goat farming.

\section{References}

Abdulai, A. and Huffman, W. E. 1998. An examination of profit inefficiency of rice farmers in Northern Ghana. Staff Paper\#296. Department of Economics, Iowa State University, Ames. 27p.

Acar, M. 2010. A research on technical problems and current status in the member enterprise of Isparta breeding sheep goat association. Dissertation (M.Sc.). Suleyman Demirel University, Isparta (in Turkish).

Alemdar, T. and Işik, H. 2008. Technical efficiency of peanut growing farms in Turkey. Acta Scientiarum Polonorum, Oeconomia 7:5-15.

Alemdar, T. and Ören, M. N. 2006. Determinants of technical efficiency of wheat farming in Southeastern Anatolia, Turkey: a nonparametric technical efficiency analysis. Journal of Applied Sciences 6:827-830.

Araç, B. 2007. The Structural characteristics of goat farms of Diyarbakir province. Dissertation (M.Sc.). Yüzüncü Y1l University, Van (in Turkish).

Battese, G. E. 1992. Frontier production functions and technical efficiency: a survey of empirical applications in agricultural economics. Agricultural Economics 7:185-208.
Battese, G. E.; Malik, S. J. and Gill, M. A. 1996. An investigation of technical inefficiencies of production of wheat farmers in four districts of Pakistan. Journal of Agricultural Economics 47:37-49.

Binam, J. N.; Tonye, J.; Nyambi, G. and Akoa, M. 2004. Factors affecting the technical efficiency among smallholder farmers in the slash and burn agriculture zone of Cameroon. Food Policy 29:531-545.

Brandano, P.; Pulina, G. and Raasu, S. P. G. 1992. Quality and quality aspects of goat production in Italy. Medit 3:16-25.

Boussofiane, A.; Dyson, R. G. and Thanassoulis, E. 1992. Applied data envelopment analysis. European Journal of Operation Research, 52:1-15.

Chirwa, E. W. 2003. Sources of technical efficiency among smallholder maize farmers in Southern Malawi. Wadonda Consult Working Paper WC/01/03. 22p.

Cinemre, H. A.; Ceyhan, V.; Bozoğlu, M.; Demiryürek, K. and Kilıç, O. 2006. The cost efficiency of trout farms in the Black Sea Region, Turkey. Aquaculture 251:324-332.

Cloutier, L. M. and Rowley, R. 1993. Relative technical efficiency: data envelopment analysis and Quebec's dairy farms. Canadian Journal of Agricultural Economics 41:169-176.

Coelli, T. J. 1996. A guide to DEAP Version 2.1: a data envelopment analysis (computer) program. CEPA Working Paper 96/08. Department of Econometrics, University of New England, Armidale, Australia.

Coelli, T. J. 1997. A multi stage methodology for the solution of orientated DEA models. Paper presented to the Taipei International Conference on Efficiency and Productivity Growth, Taipei.

Coelli, T. J.; Rao, D. S. P. and Battese, G. E. 1998. An introduction to efficiency and productivity analysis. Kluwer Academic Publishers, Boston.

Coelli, T. J.; Rao, D. S. P.; O’Donnell, C. J. and Battese, G. E. 2005. An introduction to efficiency and productivity analysis. 2nd ed. Springer Science+Business Media, Inc., New York, USA.

Çıtak, D. 2011. Economic analysis of the goat breeding farm: A case study at Çanakkale's Central District. Dissertation (M.Sc.). Çanakkale Onsekiz Mart University, Çanakkale (in Turkish).

Dağıstan, E.; Koç, B.; Gül, M.; Parlakay, O. and Akpınar, M. G. 2009. Identifying technical efficiency of dairy cattle management in rural areas through a non-parametric method: A case study for the East Mediterranean in Turkey. Journal of Animal and Veterinary Advances 8:863-867.

Darwich, M. 1998. Economics of crop-livestocks systems in the Abdul Aziz Mountain Area of Hassakeh province, Northeast Syria. Doctoral dissertation. Çukurova University, Adana (in Turkish).

De Rancourt, M.; Fois, N.; Lavin, M. P.; Tchakérian, E. and Vallerand, F. 2006. Mediterranean sheep and goats production: An uncertain future. Small Ruminant Research 62:167-179.

Dellal, İ. 2000. The economic analysis and planning of hair goat farms in Antalya province. Doctoral dissertation. Ankara University, Ankara (in Turkish).

Dellal, İ.; Keskin, G. and Dellal, G. 2002. Economic analysis and supply of animal products in small ruminant farms in SAP. Project Report No: 83. 86p. Institute of Agricultural Economics Research, Ankara (in Turkish).

Demircan, V.; Binici, T. and Zulauf, C. R. 2010. Assessing pure technical efficiency of dairy farms in Turkey. Agricultural Economics - Czech 56:141-148.

Deoghare, P. R. and Bhattachryya, N. K. 1993. Economic analysis of goat rearing in the Mathura district of Utter Paradesh. Indian Journal of Animal Sciences 63:439-444.

Erkus, A.; Bulbul, M.; Kiral, T.; Acil, A. F. and Demirci, R. 1995. Agricultural economics. Ankara University Faculty of Agricultural Press, Ankara (in Turkish). 
Farrell, M. J. 1957. The measurement of productive efficiency. Journal of the Royal Statistical Society Series A, III, 120:253-290.

Fousekis, P.; Spathis, P. and Tsimboukas, K. 2001. Assessing the efficiency of sheep farming in mountainous areas of Greece. A non-parametric approach. Agricultural Economics Review 2:5-15.

Fraser, I. and Cordina, D. 1999. An application of data envelopment analysis to irrigated dairy farms in Northern Victoria, Australia. Agricultural Systems 59:267-282.

Galanopoulos, K.; Abas, Z.; Laga, V.; Hatziminaoglou, I. and Boyazoglu, J. 2011. The technical efficiency of transhumance sheep and goat farms and the effect of EU subsidies: Do small farms benefit more than large farms? Small Ruminant Research 100:1-7.

Galanopoulos, K.; Aggelopoulos, S.; Kamenidou, I. and Mattas, K. 2006. Assessing the effects of managerial and production practices on the efficiency of commercial pig farming. Agricultural Systems 88:125-141.

Gaspar, P.; Escribano, A. J.; Mesías, F. J.; Escribano, M. and Pulido, A. F. 2011. Goat systems of Villuercas-Ibores area in SW Spain: Problems and perspectives of traditional farming systems. Small Ruminant Research 97:1-11.

Gaspar, P.; Mesías, F. J.; Escribano, M. and Pulido, F. 2009. Assessing the technical efficiency of extensive livestock farming systems in Extremadura, Spain. Livestock Science 121:7-14.

Gebremedhin, T. G. and Gebrelul, S. 1992. An investment analysis of meat goat enterprises for small-scale producers. Review of Agricultural Economics 14:45-33.

Gerber, J. and Franks, J. 2001. Technical efficiency and benchmarking in dairy enterprises. Farm Management 10:715-728

Gonçalves, A. L.; Lana, R. P.; Vieira, R. A. M.; Henrique, D. S.; Mancio, A. B. and Pereira, J. C. 2008. Avaliação de sistemas de produção de caprinos leiteiros na região sudeste do Brasil. Revista Brasileira de Zootecnia 37:366-376.

Gül, M. 2005. Technical efficiency and productivity of apple farming in Antalya province of Turkey. Pakistan Journal of Biological Sciences 8:1533-1540.

Gül, M. 2006. Technical efficiency of apple farming in Turkey: A case study covering Isparta, Karaman and Nigde provinces. Pakistan Journal of Biological Sciences 9:601-605.

Gul, M.; Koc, B.; Dagistan, E.; Akpinar, M. G. and Parlakay, O. 2009. Determination of technical efficiency in cotton growing farms in Turkey: A case study of Cukurova region. African Journal of Agricultural Research 4:944-949.

Hansen, B. G.; Hegrenes, A. and Stokstad, G. 2002. Characterizing efficient dairy farms and farmers. p.123-136. In: Farm management. Proceedings of NJF Seminar No. 345. NILF-report 2003-2. Norway.

Hansson, H. 2007. Strategy factors as drivers and restraints on dairy farm performance: evidence from Sweden. Agricultural Systems 94:726-737.

Idiong, I. C. 2007. Estimation of farm level technical efficiency in smallscale swamp rice production in cross river state of Nigeria: a stochastic frontier approach. World Journal of Agricultural Sciences 3:653-658.

Kaliba, A. R. and Engle, R. C. 2004. Cost efficiency of catfish farms in Chicot County, Arkansas: the impact of extension purposes. Selected paper prepared for presenting at the Southern Agricultural Economics Association Annual Meeting, Tulsa, Oklahoma. 25p.

Koc, B.; Gul, M. and Parlakay, O. 2011. Determination of technical efficiency in second crop maize growing farms in Turkey: A case study for the East Mediterranean in Turkey. Asian Journal of Animal and Veterinary Advances 6:488-498.
Lund, M. and Ørum, J. E. 1997. Computerised efficiency analysis in farm business advice. Farm Management 9:507-514.

Mathijs, E. and Vranken, L. 2000. Farm restructuring efficiency in transition: evidence from Bulgaria and Hungary. Selected paper. American Agricultural Association Annual Meeting, Tampa, Florida. 26p.

Meensel, J. V.; Lauwers, L. and Huylenbroeck, G. V. 2010. Communicative diagnosis of cost saving options for reducing nitrogen emission from pig finishing. Journal of Environmental Management 91:2370-2377.

Omonona, B. T.; Egbetokun, O. A. and Akanbi, A. T. 2010. Farmers resource-use and technical efficiency in cowpea production in Nigeria. Economic Analysis and Policy 40:87-95.

Özdemir, H. 2009. The structural and breeding characteristics of Angora goat rearing in Turkey. Doctoral dissertation. Ankara University, Ankara (in Turkish).

Paksoy, M. 2007. Economic analysis of goat rearing farms for milk production in Kahramanmaraş province. Doctoral dissertation. Ankara University, Ankara (in Turkish).

Panayiotou, G. S. 1989. The economics of sheep and goat enterprises in Cyprus. Agricultural Economics Report. Agricultural Research Institute, Cyprus.

Papanagiotou, E. 1991. Some factors of goat farming profitability in Greece. Agricolture Mediterranea 121:305-311.

Parlakay, O.; Semerci, A. and Celik, A. D. 2015. Estimating technical efficiency of dairy farms in Turkey: a case study of Hatay Province. Custos e Agronegócio Online 11:106-115.

Ray, S. C. 2004. Data envelopment analysis: theory and techniques for economics and operations research. Cambridge University Press, New York.

Rehber, E. and Tipi, T. 2005. Agricultural management and planning. Publication No. 2.05-049-0425. Uludag University, Bursa.

Reinhard, S.; Lovell, K. C. A. and Thijssen, G. J. 2000. Environmental efficiency with multiple environmentally detrimental variables; estimated with SFA and DEA. European Journal of Operational Research 121:287-303.

Ruiza, F. A.; Menab, Y.; Castel, J. M.; Guinamard, C.; Bossis, N.; Caramelle-Holtz, E.; Contu, M.; Sitzia M. and Fois, N. 2009. Dairy goat grazing systems in Mediterranean regions: A comparative analysis in Spain, France and Italy. Small Ruminant Research 85:42-49.

Santos Junior, E.; Vieira, R. A. M.; Henrique, D. S. and Fernandes, A. M. 2008. Characteristics of the dairy goat primary sector at the Rio de Janeiro State, Brazil. Revista Brasileira de Zootecnia 37:773-781.

Shim, W. 2003. Applying DEA technique to library evaluation in academic research libraries. Library Trends 51:312-332.

Toussaint, G.; Morand-Fehr, P.; Castel Genis, J. M.; Choisis, J. P.; Chentouf, M.; Mena, Y.; Pacheco, F. and Ruiz, A. 2009. Technical and economic analysis and assessment methodology for sheep and goat production systems. Options Méditerranéennes. Série A, Séminaires Méditerranéens (91):327-374.

TUIK - Turkish Statistics Institute. 2014. Statistical data. Available at: $<$ http://www.tuik.gov.tr $>$. Accessed on: Dec. 14, 2014.

Vieira, R. A. M.; Cabral, A. J.; Souza, P. M.; Fernandes, A. M.; Henrique, D. S. and Real, G. S. C. P. 2009. Dairy goat husbandry amongst the household agriculture: herd and economic indexes from a case study in Rio de Janeiro, Brazil. Revista Brasileira de Zootecnia 38:204-213.

Walden, J. B. and Kirkley, J. E. 2000. Measuring technical efficiency and capacity in fisheries by data envelopment analysis using the General Algebraic Modeling System (GAMS): A workbook. Report of NOAA Technical Memorandum NMFS-NE-160. 15p. 